\title{
INTRODUCTION
}

The essays contained in this volume were presented at a symposium held at Georgetown University, September 24-26, 1993, entitled "The Question of Christian Philosophy Today." Together with excerpts from the question-and-answer sessions that followed each presentation and the concluding Roundtable discussion involving all the presenters, these essays document the proceedings of that event. Beyond that, it is possible, I believe, to discern in them something of the meaning of that event, and something of its spirit, as experienced by those who took part in it. Many participants testified that the conversation prompted by both the formal and the informal dynamics of the symposium sustained a sense of timeliness, a certain recognizable warrant of the significance of its claims upon them. From the beginning, a palpable doubt, expressed in different ways by several speakers and many of the participants, made its power felt and had a distinct effect on the way the conversation unfolded. Was there really a question here? Was there life in this question still, for us, here, today? How could that be possible? What could be the point? Like the products of Penelope's loom, the presentations were interwoven with a strand of "guilty consciousness" that foresaw the intention, the necessity, to undo in the night what had been done in the day. The experience of the symposium was one of double-doing, and from that experience, explored and compounded from session to session, there gradually emerged a recognition that, in fact, this was a warranted question; there was a real dialectic at work between present doubt and the weight of tradition and effective precedent, between hesitation and hope. For that very reason, it became clear that a genuine dialogue was possible. It could not be decided in advance what the outcome would be, or what it was possible to say regarding Christian philosophy today, or how anything could be said. It emerged, however, that, despite doubt and uncertainty, people wanted to find out. This was a timely question, because the con- 
versation it invited was wanted and needed. In that sense, it could be freely and truthfully undertaken and enjoyed.

The symposium was fortunate to be given, early on, a potent and evocative image of this sense of timeliness. William Richardson, speaking on the first evening, began his presentation by asking his listeners to look carefully at the projected image of Giorgione's The Three Ages of Man, which hangs in the Pitti Gallery in Florence, Italy, and is reproduced on the cover of this volume. He went on to suggest that in the picture as a whole, but particularly in the enigmatic expression and gaze of the old man at the left of the group, he recognized the way this experience of being in question looks on a human face. He asked us to see the question and to see it as our own, to recognize ourselves in the picture this question opens to our view.

I would like to suggest that this volume be read from the perspective this image offers us and Bill Richardson articulates and develops in his essay, "Back to the Future." To facilitate adopting that perspective, the essays are grouped here and sequenced in an order different from their order in the actual symposium program. After "Back to the Future," the second section, "Encountering the Tradition," includes five essays that attempt individually to help situate and establish the present context of the question of Christian philosophy. The third section, "Of What Avail?" comprises four essays that address in their own distinct ways the possibility of a genuinely timely Christian philosophy. The fourth section, "Philosophizing as a Christian," offers one instance of the form an individual response to the question or the look on the face of Giorgione's old man might take. Finally, the fifth and sixth sections, "A Concluding Gathering," and "In Response," offer two distinct types of reflection on the experience of the symposium.

To further suggest the possibility of adopting the viewpoint Richardson has suggested, a brief prelection of each of the papers might be in order. Without wishing to limit the possible interpretations, a point of focus can be anticipated for each.

\section{EVOKING THE QUESTION}

If there is still any point in saying that any picture is worth a thousand words, then we might well begin to appreciate that 
point as it emerges in the strategy William Richardson employs to initiate the development of the symposium. Called on to "evoke the question [of Christian philosophy today] in its fullest and most radical terms and to bespeak its timeliness for the symposium audience," Richardson responds with a performance that honors the fundamental lesson about philosophical existence and conversation which Plato taught masterfully once for all: namely, that it is a dramatic event. Philosophy occurs when life really becomes a question and is allowed to show itself as such. In what amounts to a master stroke of philosophical dramatic imagination, Richardson lets a painting, The Three Ages of Man by Giorgione, act as the dramatic metaphor that links his own personal experience of the question of the symposium happening to him on a cloudy-bright Good Friday afternoon on a bridge over the Seine after a visit to a painting exhibition, and is the plot structure by which his essay unfolds. Through this metaphor he enacts the meaning of the claim his contribution makes on us: to think about how there opens up another, different possibility between, on one hand, "Christian philosophy" as a body of ideas and, on the other, "Christian philosophers" as a combination of two distinct characteristics in a single person: philosophizing as a Christian.

After introducing his central image, Richardson carefully situates his own reflection in the context of both the Continental and the Anglo-American concern with and response to the question in the twentieth century. From this consideration there emerges not only the frame of the debate in its traditional and contemporary modes but also a sharply focused glimpse of the painting's capacity to help us enter into the history of the question for ourselves. For Richardson takes the three figures together as an image not only of the tradition, including its current issues and debates, but also of the question about the tradition that grows out of the experience of living in and through the twists and turns of its "plotting."

Richardson singles out three elements of the grouping for special consideration: the text under discussion, the personal nature of the subjects involved in the dialogue, and the gesture of the master, which suggests the function of metaphysical thinking in the tradition. Using these issues he introduces the relevance of 
voices such as those of Nietzsche, Derrida, Foucault, Lacan, Heidegger, Lyotard, and Marion. From each issi' seen through the experienced eyes of the old man the question of truth emerges, particularly the question of what binding truth-claim can speak out of texts whose fabric separates and frays within the economy of difference; from the issue of personal nature the question of the person emerges, of how Christian philosophy can ever come to grips with the radical antihumanism of postmodern thinking; and, finally, from the issue of the role of metaphysics comes the question of history, particularly the question of the relation of Time and Being that Christianity claims is given a uniquely privileged resolution in the Incarnation of Jesus Christ. In this regard, Richardson gives special attention to the response of Jean-Luc Marion in God Without Being, and goes on to suggest what Richardson says he sees as "one more step in the direction that Marion's proposal has opened up": a sketch of Richardson's conception of what it means "to philosophize as Christians." What Richardson has to say in developing this suggestion is intended not as an answer but only as an opening up and bringing to light, a "clarifying" of the question. But in that light, under the penetrating gaze of the old man's eyes, something else comes to light, belonging not to any individual but to the subject itself and to us all in relation to it-resistance, the resistance to experiencing the question as addressed to us, individually and communally, personally. " 'I resist being looked at in that way and asked so directly: Well and good, but what about you? Where do you stand? Or will you walk away?" 'That resistance is the impulse that sets the rest of the symposium to work.

\section{ENCOUNTERING THE TRADition}

Speaking from the perspective of one educated "at Cornell in the early 1960s and by life in America's analytical philosophy circles since," Marilyn McCord Adams offers a pointed focus on the "Francophone" controversy that developed between Gilson and Van Steenberghen sixty years ago regarding the challenges of Christian philosophy in the twentieth century. Using a sketch of the battle lines drawn in that debate, Adams pursues a tactic 
first employed perhaps by Plato in his Protagoras: offering a characterization of philosophy and philosophers by exploring the dimensions and dynamics of the process of education which its nature requires. In her contribution, "History of Philosophy as Tutor of Christian Philosophy," she speaks autobiographically of her professional upbringing in the "borderline 'abusive home" of Anglo-American analytic philosophy. Avoiding caricature and recrimination, and recognizing a range of good intellectual and professional habits that that pedagogy inculcated, she allows herself to become explicitly conscious of the thin "ontological diet" on which she learned to subsist and its deficiency for nourishing the commitments and intuitions for which her identity as a Christian would naturally have hoped a hardier fare. Her metaphors, carefully balanced and with a ring not only of familiarity but also of truth for many of her colleagues, give a new and timely appropriateness to Anselm's characterization of fides quaerens intellectum. It is in this context that she suggests that many, or even most, of us who are concerned with the question of Christian philosophy today and who have grown up in the analytical school "will be helped in recovering our identity as Christian philosophers by putting ourselves to school in the history of Christian philosophy in the Middle Ages." One thousand years of richly textured tradition that prized analytical rigor, yet resisted artificial structures within the identity of its teachers and pupils, can, Adams argues, serve as a tutor and guide to the development process wherein we learn first to "try on for size" the ways of thinking and the issues that together formed the philosophical identities of great persons who could serve as "role models" and from whom we can learn not just by imitation, but also by recapitulating for ourselves their achievement of learning to think for themselves as Christians. Unspoken throughout her essay is the invitation to those of her colleagues who were brought up and now have gained their maturity in other "philosophical households," especially the modern European metaphysical tradition or contemporary postmodern heritage, to allow themselves to become conscious both of their relationship to the analytical tradition and of the dynamics that have shaped the philosophical pedagogy by which they themselves have been formed. Adams seems to say to us all that, as Christian philoso- 
phers, we all need to spend our day as Hippocrates did, listening to and reflecting on the pedagogies that are continually shaping our philosophical souls.

In the second symposium essay, Louis Dupré continues to probe the historical roots of the issue, asking why it is that Christian philosophy has become a question today. He sketches the historical process that led to a separation between the tradition of religious thought proper and the autonomous, purely rational philosophy that emerges at the beginning of the modern age. While philosophy might yield the notion of transcendence, it cannot, he argues, lend it a positive content. This it can acquire only from an actual encounter with religious belief, so that in dealing with this specifically religious content, philosophy must be satisfied to reflect on a given, nonphilosophical experience or on a positive faith. Although classical Greek and medieval philosophy succeeded to a large extent in holding these two in a vital and creative tension, Dupré discerns a tendency in modern philosophy to blend and confuse metaphysics with the philosophy of religion, either ignoring the possibility of real transcendence or incorporating it in an autonomous metaphysics, but in either case closing off the possibility of a Christian philosophy proper. Dupré introduces as his central thesis the notion that this apparent new impossibility is a consequence of a fragmented vision of the real, in which cosmic, anthropic, and transcendent elements became divorced from one another and destroyed the ancient sense of universal harmony. More specifically, he argues that the notion of the "supernatural," relegated to the status of a detached scaffolding, became extraneous to the realm of being proper to philosophy when the concept of nature, both human and cosmic, became separated from the constitutive relation to transcendence that supported its meaning and value. In the second section of his essay, Dupré examines in detail two foci of the tensions within traditional Christian philosophy that eventually split apart, creating the fissure between the natural and the "supernatural." The first is the transmission of the Aristotelian theory of causality from its original vital contact, which Aquinas maintained even after it gained the ascendancy in his expression over the Platonic elements in his thought, to a far more mechanical and schematic notion in which the relation of Creator to cre- 
ation was reduced almost exclusively to that of efficient cause. The second and more damaging fracture, according to Dupré, was introduced by nominal thought - it is significant that he excludes Ockham from complicity in this regard-into the understanding of divine freedom. He argues that nominalist theology transformed the concept of God's potentia absoluta and its relation to the potentia ordinata in such a way as to make plausible a view of nature as a closed system of secondary causes fully equipped io act without special divine assistance and, hence, ultimately detachable from any divine "superstructure." The development of "natural theology" in the sixteenth and seventeenth centuries, which began as an attempt to reclaim the domain of transcendence for the new philosophy of the modern age, ended up a misguided foundationalist project. Faith and grace were conceived and explained as "building on" the foundation of nature, but the foundation was viewed as providing that basis independently, so that the relation ceased to be either original or organic. This recognition leads Dupré in the essay's third section to call for a restoration of Western thought's "ontological unity," through a fundamental rethinking of our philosophical approach-"a new kind of metaphysics" such as Nicholas of Cusa initiated in the fifteenth century. Although this subject is left undeveloped in Dupré's essay, he clearly points the way toward issues that later symposium contributions would consider: the overcoming of the "baneful" absolute priority of the subject, the crucial issue of the difference that arises within freedom, an ontology of immanent relation and "finite transcendence," especially with regard to the place of revelation in Christian philosophy, and the nature of the distinction between theology and philosophy.

Robert Adams's symposium contribution is motivated by an interest in studying the complex dynamics that characterize the interplay of Christian theology and philosophy as they have operated historically, insofar as they can be discerned by carefully probing at least one important nexus of those dynamics: Kant's treatment of the subject of original sin. As Adams makes clear at the outset, however, and again in his conclusion, such an interest has a hermeneutical relevance that extends beyond historical comprehension to a recognition of its application for our contem- 
porary understanding of the way such questions are playing themselves out in our own society and ways of thinking. Citing the importance of Reinhold Niebuhr's work, which he styles as "at once social criticism, political ethics, and Christian apologetics," Adams argues that behind Niebuhr's most famous project, his exposition and rehabilitation of the doctrine of original sin, stands Kant's treatment of the subject and the view that the topics of sin and forgiveness belong both to the Christian tradition and to a treatment of Religion Within the Limits of Reason Alone. Although one might argue that this view of Kant's is itself idiosyncratic or, at least, peculiar to his historical situation, Adam's analysis of the roots of Kant's position in the contrast of the Scholastic approach of Aquinas, based on a faculty psychology, with Melanchthon's version of the Reformers' view, which departs from the medieval style of thinking about the will and responsibility, reveals a philosophical issue central to both ethical theory and the issue of human personhood. Through a careful and detailed account of the similarities and differences of Kant's view with these two influential predecessors concerning the relation between voluntariness and our responsibility for motivational states-especially our deepest motivation, which Kant refers to as our "ultimate subjective ground of choice"-Adams offers a lucid demonstration of what Gadamer might refer to as wirkungsgeschichtliche Bewußtsein (historically effected consciousness) working itself out in the human dialogue between theological and philosophical concern and understanding for a genuinely shared subject matter. Adams's reflection reaches a double climax in relation to the question of the symposium. First, it invites us to consider the implications of its historical reflection on our contemporary consideration of the nature of human moral agency and personhood. Second, it provokes us to confront the fact that from the Middle Ages to the early modern period "important parts of the development of conceptions of the voluntary and of moral responsibility . . . took place in the context of discussions of original sin." As Adams draws his conclusion that it would be "fatuous" to expect to comprehend these philosophical developments apart from the context of their embeddedness in a theological question, the stage is set for the reflection that later symposium contributions will give to the implication of this con- 
clusion for our own participation in the dialogue between these two abiding human concerns: the philosophical and the religious.

The question of the possibility and promise of philosophizing as a Christian emerges as the central focus of Adriann Peperzak's essay, "The Problem of Christian Philosophy." The strength and value of his contribution lies in the gentle but firm spirit of irony Peperzak is able to bring to the discussion of three questions that formulate the problematic character of his theme. First, he asks "What is philosophy and how is a philosopher engaged in it?" Finding the path to a satisfactory response blocked by peculiarly modern assumptions which obscure the original features of philosophical existence as a passionately committed way of life, he gradually works to gain a view of philosophy in which the relationship among wisdom, life, and theory is restored to the integrity it genuinely enjoyed in so much of the practice of classical and medieval philosophers and to which many developments in postmodernist thought promise at least the possibility of a return. At the core of this integrity, Peperzak identifies an openness to human affectivity as responsive and responsible which both capacitates and requires an involvement with life which takes the form of a process of purification and, as such, is appropriately viewed as a spirituality.

Peperzak's second thematic issue concerns what we should understand by the word Christian. Again, the ironic tone of the response leads us first to consider all that is not (yet or fully) Christian as mysteriously yet inseparably a part of whatever is Christian. Here he evokes the ambiguity that is characteristic, though in different ways, of the Incarnation as the content of faith and of human sinfulness as the enemy of faith. As a consequence, the life of Christian faith, too, is a process of purification that rejects sin by forbidding "idolatry," any absolutization or infinitization of human culture. It is in this parallel of philosophy and Christian faith as human experiences of a process of purification-different in their original commitment, self-understanding, and practice, yet connected by this passionate involvement and responsibility-that Peperzak discerns an opening for the practice of an authentic Christian philosophy.

Thus is he led to consider his third question concerning the connections between philosophical and Christian moments in a 
person who makes both commitments. Here the negativity of irony passes over cautiously to the more hopeful but no less ironic suggestion of a logic of integration of the two, in which a transformation of both the life of Christian faith and the life of philosophy occurs, allowing both to honor the determinacy of their original Yes or Amen, while entering into a growing intimacy of lived commitment and mutual effective recognition. Lest this hope sound like too facile a nostalgia for the "marriage of faith and reason," Peperzak insists on the limits as well as the difficulties of such a process of integration. Nevertheless, behind his conclusion that "A post-postmodern renaissance of Christian spirituality in philosophy is necessary" stands the author's demonstrated conviction that it is also possible.

In "A Theological View of Philosophy: Revelation and Reason," David Tracy focuses attention more sharply on two points - one, the theological category of revelation; the other, philosophical hermeneutics - in an attempt to illustrate one way in which theology can and, indeed, must relate in significant ways to philosophy, insofar as a revelation-constituted understanding of faith as knowledge is a meaningful cognitive claim. Arguing that the philosophy of religion, as a distinctly modern development, has the effect of losing the Christian emphasis on divine self-revelation through the Incarnate Word, Tracy explores the opposing constraints that fideism and rationalism, in all their protean forms, introduce into the effort to reconcile the legitimate claims of both philosophy and theology to interpret the possibility of a form of human knowledge which arises in faith. He then goes on to offer a theological construal of revelation as an event of divine self-manifestation in the event and person of Jesus the Christ. Focusing on three elements of this notion of revelation-event, manifestation, and Word-he shows how hermeneutic philosophy can make a contribution to our comprehension of the notion of revelation which goes beyond merely analytic classification to genuine development. Tracy identifies two distinct dynamics in the hermeneutical dialectic of the Word: as Logos, the Word is disclosive manifestation; as Kerygma, the Word is disruptive proclamation. This distinction not only allows for a way of understanding all the classic dichotomies of Christian theological self-understanding-for instance, incarnation/ 
cross, sacrament/word, analogy/dialectic, love/justice, participation/distance, and the like-but also serves to make unmistakable the necessarily hermeneutic character of Christian faith: the written texts called Scripture assure that the Christ of the present Christian community is the same Christ testified to by the apostolic witnesses as the decisive self-manifestation of God and humanity. What is revealed in and through Christ as manifested in the witness-word of Scripture is a new possibility for human existence: Love. Faith is a knowledge born of revelation that God is Love and human beings are loved creatively and redemptively by God, and are therefore empowered and commanded to love in their turn. Through revelation, Tracy concludes, all Being is now known as gracious.

For Tracy, hermeneutics is a particularly appropriate way of understanding Christian existence as participation in the knowledge of faith. He identifies five specific elements that this appropriateness comprises: (1) hermeneutics accords priority to "possibility" over "actuality"; (2) it takes history and human historicity with full seriousness; (3) it offers an understanding of truth as manifestation which, unlike coherence or correspondence theories, is fruitful for a view of revelation as the event of God's self-manifestation; (4) it clarifies, through its emphasis on textuality, the role of form as the imaginative embodiment of a possible mode of being in the world; and (5) through its dialogical model of understanding, it opens the way to an ethics of understanding the Good and the gracious transformation of all Being by Love. Tracy concludes by suggesting two general dynamics that could characterize the interpretation of hermeneutic philosophy and a Christian theology of revelation. First, theology can offer the possibility of reconstructing the basic categories of hermeneutic philosophy in accordance with the Form of Christian revelation, the person of Jesus Christ. Second, hermeneutics provides a new way to clarify, challenge, and even connect theology's understanding of revelation as manifestation of a reasonable, even if formerly unimagined, possibility for human existence. Finally, Tracy suggests that hermeneutics can also offer a way to reestablish an effective connection between theology and spirituality through its commitment to thinking (recollection) as an ontological element of being in the world and to 
dialogue (prayer as conversation) as the most fundamental of disciplines.

\section{OF What AvaIL?}

In his symposium contribution, Patrick Heelan identifies Bernard Lonergan, S.J., as one of the few philosopher/theologians of our time who has written with genius on both the philosophy of science and the philosophy of religion and made a significant contribution to the discussion-or, more precisely, to the appropriate method for a discussion - of whether through a common method with science one could arrive at a theology of the Christian God. In Insight he, like Aquinas, failed to resolve the question. Later, in Method in Theology and other works, he came to address the elements missing from Insight. Heelan proposes to show that if the apparatus of Method in Theology is applied to complement Insight, one has at hand both a truly sophisticated philosophy of natural science and a method in theology that embraces both the natural sciences and theology.

Heelan argues that a philosophy of science according to Insight would be enriched by adopting the hermeneutical modes of inquiry studied in Method. The former comprises 'data,' 'insight,' 'judgment,' and 'decision.' The latter comprises 'conversion,' 'horizon,' 'history,' and the structure of 'belief.' The latter are especially pertinent to the study of scientific decisions made during phases of laboratory experimentation. He also proposes that theology should add the empirical/rational modes of Insight to the hermeneutical modes of Method in its search to express the scientific and philosophical grounds of a faith community. While the hermeneutical modes traditionally focus on the literary and historical sources of a faith community, such as its scriptures, rituals, and the documents of its Magisterium, the empirical/rational modes study existing communities of faith on the model of Insight. These involve the identification of true communities of faith, and the use of traditional criteria such as the 'spiritual senses' that are used within the context of the institutional life of the community.

Heelan does not argue that a contemporary theology pursued 
in this way would guarantee that the natural and social sciences reveal the God of the Bible. What it shows is merely that if, as Lonergan supposes, there is a common philosophically understood method underlying theology and science, then using that method within the established traditions of Christian life and practice, scientists who are Christian and theologians who respect the processes of science should be able to share reliable experiential, intellectual, and rational knowledge both of nature, the subject matter of the natural sciences, and of the Christian Trinitarian God, the subject matter of the Christian religion, crossing back and forth with ease the frontier between science and theology.

In his essay, "Metanoetics: Elements of a Postmodern Christian Philosophy," John D. Caputo takes up questions remarkably closely aligned with those Richardson raised. His working hypothesis is that, if we have eyes to see and ears to hear, we can discern deep affinities between the themes and concerns of postmodernism and those of the New Testament. In a bold stroke, Caputo announces that by "Christian philosophy" he means, "at least minimally, thinking philosophically within the context and the framework of the New Testament," where that "context" functions as a way of being in the world whose categories we philosophers need and want to understand. Caputo dubs the endeavors to achieve such an understanding a "hermeneutics of the Kingdom," asserting thereby that the traditional distinction between faith and reason is, in this new dispensation, to be suspended, placed under epochè. This amounts to a contemporary "de-Hellenization" of the Greek contribution to "Christian philosophy," an exposure to its Jewish "other" which nonetheless allows it to be more itself. Appealing principally to Heidegger and Levinas, Caputo argues that contemporary postmodernist thought characteristically "goes back, in part, to originally philosophico-religious projects that are motivated by a reading of biblical sources." He develops a view of the New Testament in which the distinction between philosophy and theology is muted in favor of a reading of Scripture that offers an "alternate categoricality" in which the categories of onto-theology are simply not in play.

This development proceeds in three steps: a generalized meta- 
noetics, the kingdom of anarchy, and being and time in the kingdom. (That these three steps are closely aligned with Richardson's three questions is left to the reader to verify for him- or herself.) The first task is to establish a generalized sense of what "metanoetics" would mean as a way of thinking that especially emphasizes change or "conversion"-literally, changing one's "mind," one's way of thinking, and changing it in such a way that it itself eventually turns into a change of heart, or perhaps even that mind and heart become interchangeablethereby suggesting in advance an idea that Caputo thematizes as the New Testament portrayal of a "kingdom of metamorphosis." Underscoring the New Testament's preoccupation with "bodies" and particularly with their needs and maladies, Caputo argues that in Jesus's kingdom of metamorphosis metanoein and therapeuein always went hand in hand and that these two dynamics of existence necessarily came together in the process of immersing (baptizein) one's whole self, heart and mind, in the cleansing element of transformation. Once it has been entered, however, this transformed element of existence displays itself as a kingdom of anarchy, the principal rule of which is that, in general, rules are suspect. The distinction between phronesis and kardia parallels, in Caputo's view, the difference between, on one hand, ethics as the thoughtful, prudent application of the general rules to particular situations and mercy, on the other, as the suspension of the rules altogether. Forgiveness, the first and only law of the kingdom, is precisely anarchic: it does not look back to first principles so as to apply them to past deeds, but, rather, looks ahead to what the change of heart announced by metanoia promises. This leads Caputo to his third step: a consideration of the temporality of forgiveness, the new relation of time and being in the kingdom of metamorphosis, where what is most real about things is not their permanent structure, their deep essence, but what happens to them. To know the reality of this kingdom is to say of it, "Let it happen; may it come!" Caputo concludes by challenging his readers to consider whether it might not be precisely the way of thinking that postmodernism and the New Testament show signs of sharing that could make Christian philosophy possible today.

One ironic effect of the symposium, especially for those in- 
volved in its organization but also in the experience of the participants, was the way it called attention to a difficulty in evoking the question of Christian philosophy particularly in regard to one ineluctable aspect of its timeliness: the need and the desire to engage in dialogue the concerns and contributions of contemporary feminist thought. Far from being solely a theoretical issue, the actual difficulty appears most tangibly in finding participants capable of bringing these two concerns close enough together in their own experience and thought to enter readily and effectively into the conversation. So, more by way of default than by choice, the symposium took place without including a presentation that deliberately set out to address the question of Christian philosophy today from a feminist perspective.

It stands as a double irony, then, that for the publication of the symposium proceedings, we are able to include an essay that, though not presented as part of the original event, directly evokes and speaks out of the voice that was lacking then. The essay by Amy Hollywood, entitled "Divine Woman/Divine Women: The Return of the Sacred in Bataille, Lacan, and Irigaray," attempts to suggest how radical the disruption of our experience of the question can become once the possibility is raised of deconstructing both its traditional and its contemporary reception following the traces of the masculine and patriarchal exclusions that are inscribed in its language and imagination. Hollywood's essay invites us to consider, through reflection on the nuanced interactions of the thought of Bataille, Lacan, and Irigaray, just how open the possibilities for renewing the question of Christian philosophy today might be and, at the same time, how formidable the difficulties.

In "Christian Philosophy: Hermeneutic or Heuristic?" JeanLuc Marion makes a contribution notable both for the clarity and forthrightness of its affirmation of "Christian philosophy" as an undertaking and for the radical originality of the way he proposes to understand what that undertaking means. His essay can well be seen as an imaginative meditation on Richardson's characterization of the possibility of "philosophizing as a Christian." At the same time, Marion's study engages Caputo's conception of Christian philosophy as a "radical hermeneutic of the Kingdom" and offers an alternative model at once closer to the heuristic 
method of Husserl's phenomenology yet in solidarity with Caputo's direct appeal to the Jesus of the Gospel as the ultimate "fact" of revelation.

The study unfolds as an argument for a different construal of Étienne Gilson's definition of Christian philosophy from the one Gilson himself defended. Gilson argues that Christian revelation intervenes as an "indispensable auxiliary of reason," not because it offers to reason themes that otherwise would be inaccessible to it, but because it offers a radically original interpretation of them in the light of the revelation of Christ. Marion identifies widespread historical and contemporary evidence of philosophical practice that could well be viewed as conforming to this hermeneutic model of Christian philosophy, but goes on to propose three telling objections to so understanding it: to reduce Christian philosophy to a hermeneutic amounts to (1) denying it the level of philosophy; (2) branding it as arbitrary; and (3) reducing faith to its preambula.

Marion proposes, as a complement to the purely hermeneutic view of Christian philosophy, an extended understanding of the sense in which revelation can be an auxiliary to reason, not simply as a new interpretation of phenomena that are already visible, but also as making visible of phenomena that would have remained invisible without it. Using Pascal's threefold distinction of the order of charity, the order of spirit, and the order of the flesh, Marion argues that the order of charity, which is revealed in the person and life of Jesus, is genuinely a "new creation" that cannot be known from within either of the other orders and contains "facts" they do not. The heuristic of charity provides phenomena discovered by revelation and offers them not only to theology but to a philosophy that would examine them under the natural light of reason. The example he offers is a reflection on what it means to see the face of another person. In this sense, Marion argues, "Christian philosophy" compromises theology as much as philosophy, because its concept, the Incarnation, is intrinsically contrary. The acceptance of this scandal requires faith, but its acceptance makes it possible to "philosophize as a Christian." This proposal, startling in its inversion of the traditional relation of the elements of nature and grace as they are viewed working in Christian philosophy, is elaborated in Mari- 
on's careful consideration of four possible objections to it. He concludes with a hopeful suggestion that a Christian philosophy which is done by introducing and discovering phenomena that come from a heuristic of charity, as revealed in Christ but now inscribed historically in the world, could contribute in a determining way to a transformation of philosophy already under way at the close of our century which would restore its original dedication to "its forgotten ambition of loving wisdom."

\section{Philosophizing as a Christian}

In the essay by Jean Ladrière the work of the symposium reaches its climax. Although its author would certainly dismiss any claim to finality or privileged uniqueness regarding methodology, the essay nevertheless earns by its performance our recognition of it as an exemplary fulfillment of the best legitimate hopes of all the participants. Gathering many of the themes of other speakers, Ladrière undertakes to lay out before us, not an argument for the possibility of a fully articulated and reconciled "Christian philosophy," but an enactment of that possibility in its basic and essential elements, fully self-conscious of its challenge and task, yet never allowing itself simply to rest in this awareness but pressing, almost relentlessly, onward to their realization. Here we have a warrant for the truth-claim of Christian philosophy, offered in the achievement of the harmony of logos and ergon, word and deed, which is the credential identified by Plato for recognizing the philosophical authenticity of Socratic existence: its manifest human integrity.

\section{A Concluding Roundtable Discussion}

Perhaps the most remarkable aspect of the symposium as an event was the way in which it concluded: with a gathering, indeed, of fragments, but fragments for which the participants found ample reason to be grateful. What they found and how it transformed their experience and opened their eyes to new possi- 
bilities for meaning in the question of Christian philosophy today is presented here in their own words.

\section{IN RESPONSE}

In place of a conclusion, and in the spirit of attempting to continue the conversation the symposium initiated, the final contribution to this volume is a paper inspired by and attempting to realize some of the promptings that I took from the proceedings. Entitled "On Seeing Fra Angelico's San Marco Annunciation: The Place of Art," it follows the example set by William Richardson in his "Back to the Future" presentation and begins with another painting, a fresco, that can be seen in the city of Florence. Using an explicitly interdisciplinary method, it offers a hermeneutic approach to understanding the "place" of art in human existence, exploring the possible philosophical significance of "Incarnation" for understanding more generally how the Divine "takes place" in history. 